\title{
Should Taxpayers Have Access to the International Tax Arbitration Procedure?
}

\author{
Gilda Almeida \\ University of Miami Law School, Miami,USA, ga443@georgetown.edu
}

\begin{abstract}
Globalization has subjected corporations to multi-jurisdictional tax systems. As a result, crossborder entities are exposed to the possibility of being audited and undergoing tax adjustments more than once for their transactions. In addition, various states' measures - such as Tax Information Exchange Agreements (TIEA) and the Foreign Account Tax Compliance Act (FATCA) - have promoted international cooperation, thereby allowing tax authorities to have access to a vast volume of data. The risk of double taxation has greatly increased due to the multi-jurisdictional authorities' easy access to data. To address and balance the overlap of jurisdictions in tax matters, states are signing bilateral and multilateral treaties consenting to mandatory and binding tax arbitration, thereby expanding states' mutual agreement procedure "MAP," a historic competent authority negotiation process. However, taxpayers are not part of the arbitration process. The focus of this analysis is on demonstrating the benefits of taxpayers' access to the state-to-state MAP arbitration procedure, which was intended to provide taxpayers relief from double taxation.
\end{abstract}

KEYWORDS: Action 14, arm's length, Base Erosion Profit Shifting (BEPS), diplomatic protection, international taxation, investment arbitration, mutual agreement procedure (MAP), OECD, Section 482, Tax arbitration, transfer pricing

\section{Introduction}

As corporations became global, so do their tax concerns. States have expanded their tax jurisdictions and rely on exchange of information treaties for effective taxation. Thus, corporations are exposed to the risk of double taxation. On the other side, corporations have put in place sophisticated tax planning to maximize their after-tax results by shifting income from high-tax jurisdictions to low ones or costs from low-tax jurisdictions to high ones. Consequently, states may face "double non-taxation."

The Organization for Economic Cooperation and Development (OECD) pioneered the Base Erosion Profit Shifting (BEPS) project, which addresses taxpayers and states' concerns about better aligning taxation rights internationally (Bonnet and Pit 2018, 428). The project consists of several action plans and deadlines for their implementation (OECD 2015, 13).

This study emphasizes Action 14 of BEPS, which calls for binding arbitration for unsettled Mutual Agreement Procedures (MAPs) among OECD members (OECD 2017, 429).

Mutual Agreement Procedure arbitration is a state-to-state procedure, from which taxpayers are currently excluded. This paper highlights the benefits of adding taxpayers to the proceedings. By giving taxpayers full access to the dispute, the objective of a fair and binding determination can be attained. Parties committed to the procedure would avoid litigation in domestic courts.

This analysis adopts the perspective of the United States, an active OECD member, and assumes transfer pricing as the arbitration subject matter.

\section{Defining Transfer Pricing}

Tax authorities expect that multinationals conduct their controlled transactions at arm's length (Avi-Yonah and Xu 2017, 7). The arm's-length standard determines that taxpayers realize the same results from their controlled transactions as would be realized if uncontrolled taxpayers engaged in the same transactions under the same circumstances.

The same expectation holds for the pricing of transactions between related parties (Levey and Steven 2007, 1). Transfer pricing concerns the pricing of transactions between related parties in a manner that conforms to the arm's-length standard. Thus, transfer pricing provisions limit related entities' control over their inter-company prices and create barriers that prevent profit from shifting within the group (Levey and Steven 2007, 454). 
Transfer-pricing regulations include the following categories: i) Transfer and Use of Tangible Property; ii) Transfer, License and Use of Intangible Property; iii) Cost-Sharing Agreement; iv) Service; and v) Use of Funds (e.g., loans) 26 C.F.R. § 1.482-0 (Lexis Advance through the July 23, 2018 issue of the Federal Register. Title 3 is current through July 6, 2018).

Section 482 of U.S. Code Title 26 authorizes the Internal Revenue Service (IRS) to allocate income among related entities in a manner that "clearly reflects income" and conforms to the arm 'slength standard (Bittker and Lokken 2016/2017, 79.1). For example, the U.S. tax authority can proceed with an adjustment if a taxpayer does not comply with U.S. transfer pricing standards. However, the same can be true for other countries in regards to the same cross-border transaction, which leads to the risk of double taxation and creates uncertainty for the taxpayer (Markham 2005, 68). In this case, taxpayers have procedural alternatives, including a request for MAP that could eliminate the burden of double taxation from a treaty partner country (Ault 2013, 28-29, Example 2).

\section{What is a Mutual Agreement Procedure?}

Tax treaties usually include a MAP provision for the competent tax authorities of both countries to settle disputes over a taxpayer's transfer pricing adjustments (Bantekas 2008, 184). The goal is to reach an agreement on the taxpayer's primary adjustment (an upward adjustment) and correlative adjustment (a shift downward) (Levey and Steven 2007, 515-520).

Often, the taxpayer requests the initiation of a MAP concerning a transfer pricing adjustment, thereby supplementing the domestic procedure remedy. Taxpayers - both individuals and entities can access MAP assistance, and there is usually no minimum threshold for the disputed amount (Raad 2001, 212-213).

As of July 2018, the United States is part of 67 income tax treaties. All treaties provide a MAP provision for disputes over the interpretation and application of tax provisions to prevent double taxation. Presently, treaties with Belgium, Germany, Canada, and France incorporate mandatory and binding arbitration procedure as the last stage of the MAP. Treaties with Japan, Spain, and Switzerland have had the arbitration provision added to their protocols. Other states - including Ireland, Italy, Kazakhstan, Mexico, and the Netherlands - are in negotiations to incorporate the same measurements (Internal Revenue Service, Income Tax Treaties A to Z).

Despite long MAP procedures, competent authorities frequently do not come to agreements because of MAP's non-binding nature (Lang and Wiman 2014, 202). In some cases, competent authorities have indeed reached an agreement, but without completely removing the taxpayer's double tax burden (Ault 2005, 139). Consequently, tax arbitration can be a successful way to solve taxpayers' double tax burden, as MAP has not been effective.

Members of OECD are committed to the inclusive framework of BEPS Action 14. Furthermore, in 2016, the United States revised its treaty model to incorporate a provision referring non-settled MAP cases to arbitration after two years (U.S. Department of Treasure 2016).

The arbitral body includes a board of three members: one appointed by each competent authority, and the third chosen by both selected arbitrators. The final determination (award) does not set a precedent for other cases. The United States entered into an agreement with the International Centre for Dispute Resolution (ICDR), headquartered in New York, to provide administrative services for MAP arbitrations. The ICDR currently carries out the international operations of the American Arbitration Association. The ICDR and its affiliations cover over 40 countries and are responsible for choosing arbitrators, handling case management, and providing training.

\section{States' Sovereignty}

Many questions have arisen regarding how to define tax sovereignty in today's context. The concept of sovereignty has changed over time based on the historical framework. The definition of sovereignty was initially based on the concept of the power of a state to tax, which was entirely restricted to a state's territorial borders. Over time, however, the economy has become globalized, as has the power of taxation. Taxpayers have expanded their activities into multiple jurisdictions through subsidiaries, partnerships, branches, permanent establishments, and the internet (Santos and Rocha 2017, 30, 37). 
Tax administrations have also expanded their taxation powers across borders, touching legal transactions that relate to the state in any way. The United States, for example, taxes its citizens on the basis of their worldwide incomes, even if they reside outside of the country and do not have a source of income in the United States. 26 C.F.R. $\S 1.871-13$ (Lexis Advance through the July 23, 2018 issue of the Federal Register. Title 3 is current through July 6, 2018).

No international law imposes limits on what a state can consider a taxable event, so more than one state can claim that a legal transaction is connected to its country, thereby leaving taxpayers at risk of being taxed by multiple countries for the same transaction.

Action 14 of BEPS may redefine the concept of tax sovereignty for those countries that agree to comply with a new set of international standards regarding tax dispute matters. However, some developing countries do not want to adhere to the arbitration provision and invoke their constitutional rights to tax and enforce taxation (Brauner 2017, 73). These countries' concerns include being compelled to concede tax credits, allowances, or tax exceptions that may be unjustified in a domestic context and, additionally, authorizing an independent private arbitrator to decide on their taxation rights. Furthermore, developing countries see themselves as occupying a vulnerable position (AviYonah 2000, 1643). The binding arbitration provision would restrict their taxation powers, and they would gradually be controlled by more powerful nations.

This paper argues that the MAP arbitration model would benefit developing countries because a "tax-friendly" country is an ideal host state for investments (Dolzer and Schreuer 2012, 22). By not committing to the treaty arbitration provision, such states may face decreased investments and consequently less state tax revenue. The global economic framework and the risk of reduced investments could lead to the expansion of the state's definition of tax sovereignty. Soon, sovereignty will not be an excuse for a state to not commit to arbitration as a form of dispute resolution.

\section{Taxpayers' Access to MAP Arbitration}

Currently, tax arbitration is the exclusive mechanism available to solve an international double-taxation dispute. Similar to the diplomatic protection doctrine, a tax dispute is carried out only by the two states involved and excludes the private party from the procedure. The states determine how to allocate taxpayers' disputed tax rights (Lang 2018, 01).

This paper argues, however, that tax disputes have unique characteristics, and taxpayer participation must be taken into account. Diplomatic protection has been developed for and is applied in international law disputes; it should not be adapted to international tax dispute resolution (Perrou 2013, 62).

Under traditional diplomatic protection, private parties who pursue claims against states lack direct access to international remedies, depending on the home state's discretion in taking private parties' claims against the host state. In a tax dispute, the taxpayer may have domestic disputes against both states; therefore, the home state would not embrace the taxpayer's interest.

Even in a non-tax dispute, the effectiveness of diplomatic protection is limited, as it depends on the states' political discretion; the investor is never in control of the process. Similarly, in tax matters, each state defends its interest in the MAP procedure or at in subsequent tax arbitration. In conclusion, neither domestic courts, MAP procedures, nor state-to-state MAP arbitration have not been effective in resolving an international tax disputes.

In a non-tax dispute - investment arbitration, for example - parties have long perceived the disadvantages of a pure state dispute, and the majority of claims now involve investors' direct access to dispute resolution, as those administrated by the International Centre for Settlement of Investment Disputes (ICSID). Likewise, the diplomatic protection model is not adequate for tax arbitration and needs to be reviewed in comparison to alternative methods granting the taxpayer direct access to arbitration alongside the home and host states.

The idea of taxpayers' participation and commitment to the arbitration procedure has advantages for all parties. Similar to investment arbitration, taxpayers' can make a choice between pursuing their claims in domestic courts or through MAP arbitration ("fork-in-the-road"). As a result of this final choice, the arbitral award would be final and binding for the states and the taxpayer. 
States could benefit from taxpayers' commitment to a final arbitral award by lowering their administrative and domestic court backload, increasing legitimacy and enhancing transparency in the arbitration process. The arbitration award would be final, binding, and enforceable, with res judicata effect. Parties would not seek further legal remedy against the award determination, encouraging other taxpayers to request MAP arbitration as an effective method for tax dispute resolution.

Taxpayers would also benefit from a final arbitration procedure. Arbitration would be a "onestop" tribunal that could efficiently and timely provide taxpayers with double taxation relief. Lengthy and costly multi-jurisdictional court proceedings would be avoided. Further, taxpayers are already familiar with other types of arbitration - such as investment or commercial arbitrations - and would welcome the procedural expansion for tax matters.

States justify the exclusion of taxpayers from the arbitration procedure because it is a state-tostate procedure, and the award rendered is binding to the states; however, this is elective for taxpayers. Currently, when a final decision is rendered, the taxpayer has the choice to accept or deny the arbitration award. Unfortunately, the lack of taxpayers' commitment to the procedure, and their ability to reject the award limits the effectiveness of MAP arbitration procedure.

From taxpayers' perspectives, the current system is not entirely successful in increasing their level of confidence and addressing the risk of double taxation. Taxpayers are still left with uncertainties, including whether or not they were granted a fair trial.

There is no reasonable justification for preventing taxpayers' participation in the MAP arbitration procedure. By signing tax treaties, a state expressly consents to waive its tax sovereignty to the other state, restricting each state's power to tax. As a consequence of a tax treaty, states can remove all or part of a taxpayers' tax obligation imposed by each contracting state's national law. Treaties are not meant to create additional tax liabilities for taxpayers; they rather seek to establish a balance in the economic relations between the contracting states. Thus, the treaty confers rights to the taxpayers as a consequence of states' consent to remove taxpayers' double tax burden.

In addition, private access to public international law disputes is feasible as it is in an investment arbitration. Allowing taxpayer's participation in the procedure could enable them to pursue their rights against one or more of the states in a dispute. Taxpayers' commitment to the arbitration procedure can be demanded early on during the MAP request or later, at the beginning of the arbitration process (submission agreement). Once the taxpayer consents to the arbitration procedure, all parties would enjoy the same rights, similar to a domestic court dispute where both taxpayer and state are in control of the proceedings at all times.

States can grant taxpayers access to the arbitration procedure progressively. At a minimum, taxpayers should have access to their case status and documents. However, for an effective MAP arbitration procedure, taxpayers should eventually enjoy equal treatment. Taxpayers' roles should mirror the roles of the other parties, including the right to appoint arbitrators, submit written or oral observations to support their views, correct or better explain facts and opinions, offer inputs regarding the terms of reference, and produce expert opinions and witness reports.

In summary, the more transparent the procedure for the taxpayer, the more assured taxpayers would be regarding the correct application of the rule of law by the arbitral tribunal. It is in taxpayers' best interest to ensure that tribunals treat them fairly. Decisions made behind closed doors make any system look opaque.

\section{Research Limitations}

Although this study was carefully drafted, there were some limitations in the research. The primary restraint is the confidentiality of MAP arbitration based on taxpayers' rights to privacy. The IRS, arbitrators, and taxpayers' representatives have a duty of nondisclosure. (Internal Revenue Service, Taxpayers Agreements for MAP Arbitration).

Yearly MAP arbitration statistics are the only information disclosed to the general public; the data is available on the IRS' website (Internal Revenue Service, Annual Competent Authority Statistics) or on the OECD's website (OECD, MAP Statistics). 
Unlike court procedures, the general public has no access to the arbitral award, or its determination over taxpayer's primary, and secondary adjustments. Further research could look into possible conflicts that may arise from general public concerns about the volume of credits or the setoffs the United States provides to a taxpayer as a result of MAP arbitration.

\section{Conclusions}

As taxpayers and states search for an adequate remedy for international tax claims, the parties should use the investment arbitration model as a basis. It has demonstrated success as a dispute resolution method and reflects changes in the economic relationship between private parties and states. Investment arbitration has moved away from diplomatic protection toward granting private parties the same status. In the case of tax arbitration, more substantial participation by taxpayers in the arbitral procedure remains a matter of state policy. However, states can grant and define the amount of access taxpayers have to the dispute. By including taxpayers in the dispute procedures, states would solve the issue of award enforcement, avoiding handling arbitration and domestic litigation, and increase the perceived fairness of the system.

\section{References}

26 U.S.C.S. $\S 482$ (LexisNexis, Lexis Advance through PL 115-196, approved 7/7/18), available from Lexis Advance ${ }^{\circledR}$. Accessed on July $25^{\text {th }}, 2018$.

26 C.F.R. § 1.482-0 (Lexis Advance through the July 23, 2018 issue of the Federal Register. Title 3 is current through July 6, 2018), available from Lexis Advance®. Accessed on July $25^{\text {th }}, 2018$.

26 C.F.R. § 1.871-13 (Lexis Advance through the July 23, 2018 issue of the Federal Register. Title 3 is current through July 6, 2018), available from Lexis Advance $\circledR$. Accessed on July $25^{\text {th }}, 2018$.

Ault, Hugh J. 2005. "Improving the Resolution of International Tax Disputes." Florida Tax Review 7:138-150.

Ault, Hugh J. 2013. Dispute Resolution: The Mutual Agreement Procedure. New York: United Nations Department of Economics and Social Affairs.

Avi-Yonah Reuven S. 2000. "Globalization, Tax Competition, and the Fiscal Crisis of the Welfare State." Harvard Law Review 113:1573.

Avi-Yonah, Reuven S., and Haiyan Xu. 2017. "Evaluating BEPS.” Erasmus Law Review 10:3-11.

Bantekas, Ilias. 2008. "The Mutual Agreement Procedure and Arbitration of Double Taxation Disputes." ACDI 1:182-204.

Bittker, Boris, and Lawrence Lokken. 2016/2017 Edition. Fundamentals of International Taxation. Cattollton, Texas: Thomson Reuters.

Bonnet, Félicie, and Harm M. Pit. 2018. "Implementing the Action 14 Minimum Standard: Signs of Improved Dispute Resolution.” Tax Notes International 90:427.

Brauner, Yariv. 2017. "An Essay on BEPS, Sovereignty, and Taxation." In Tax Sovereignty in BEPS Era, edited by Sergio A. Rocha, and Allison Christians, 73-93. Alphen aan den Rijn, The Netherlands. Kluwer Law International.

Dolzer, Rudolf, and Christoph Schreuer. 2012. Principles of International Investment Law. Oxford, U.K.: Oxford University Press.

Internal Revenue Service (IRS). Income Treaty Technical Explanation. http://www.irs.gov, search in the search bar for "treaty model explanation"; then follow "income tax treaties a to z" hyperlink. Last visited July $25^{\text {th }}, 2018$.

Internal Revenue Service (IRS). Taxpayers Agreements for MAP Arbitration. http://www.irs.gov, search in the search bar for "taxpayer MAP agreements"; then follow "Taxpayers Agreements for MAP Arbitration" hyperlink. Last visited July $25^{\text {th }}, 2018$.

Internal Revenue Service (IRS). MAP Statistics. http://www.irs.gov, search in the search bar for "competent authority statistics"; then follow "annual competent authority statistics" hyperlink. Last visited July $25^{\text {th }}, 2018$.

Lang, Michael, and Bertil Wiman. 2014. "Conference on Arbitration in Tax Treaty Law - Uppsala University - 22 August 2013." Intertax 42(3): 202-202.

Lang, Michael. 2018. Qualification Conflicts - Global Tax Treaty Commentaries, Global Tax Treaty Commentaries IBFD.

Levey, Marc M., and Steven C. Wrappe. 2007. Transfer Pricing: Rules, Compliance and Controversy. Fourth Edition. Deventer, The Netherlands: Wolters Kluwer.

Markham, Michelle. 2005. "The Resolution of Transfer Pricing Disputes Through Arbitration." Intertax: International Tax Review 33:68-74.

OECD. 2017. Model Tax Convention on Income and on Capital: Condensed Version 2017, OECD Publishing, Paris, https://doi.org/10.1787/mtc_cond-2017-en. Last visited July $25^{\text {th }}, 2018$.

OECD. 2018. "MAP Statistics." http://www.oecd.org, search in the search bar for "MAP statistics"; then follow "OECD releases mutual agreement procedure (MAP) statistics for 2016" hyperlink. Last visited July $25^{\text {th }}, 2018$.

OECD. 2015. Making Dispute Resolution Mechanisms More Effective, Action 14 - 2015 Final Report, OECD/G20 Base Erosion and Profit Shifting Project, Paris, France: OECD Publishing, Paris. Last visited July $25^{\text {th }}, 2018$.

https://doi.org/10.1787/9789264241633-en. 
Perrou, Katerina. 2013. Taxpayer Participation in Tax Treaty Dispute Resolution. Amsterdam, The Netherlands: International Bureau of Fiscal Documentation.

Raad, Kees van. 2001. "International Coordination of Tax Treaty Interpretation and Application." Intertax: International Tax Review 29(6/7):212-218.

Santos, Ramon T., and Sergio A. Rocha. 2017. "Tax Sovereignty and Digital Economy in Post-BEPS Times.” In Tax Sovereignty in the BEPS Era, edited by Sergio A. Rocha, and Allison Christians, 29-46. Alphen aan den Rijn, The Netherlands. Kluwer Law International.

U.S. Department of Treasure. 2016. U.S. Model Treaty, http://www.treasury.gov, search in the search bar for "2016 model income tax convention"; then follow "United States Model Income Tax Convention" hyperlink. Last visited July $25^{\text {th }}, 2018$. 